\title{
Role of Financial Literacy and Peer Effect in Promotion of Financial Market Participation: Empirical Evidence in Vietnam*
}

\author{
Thi Anh Nhu NGUYEN ${ }^{1}$, Kieu Minh NGUYEN²
}

Received: April 13, 2020 Revised: April 25, 2020 Accepted: May 07, 2020

\begin{abstract}
The research examines how interactions of financial literacy and peer effect indicators impact financial market participation of Vietnamese investors. In this research, financial literacy indicator is constructed from two levels, namely, basic financial literacy and advanced financial literacy. An empirical study was carried out by investigating 387 individuals who are currently working in finance-related areas such as banking, insurance and real estate industries. The findings indicate that individuals with higher level of financial literacy, specifically those with advanced financial literacy level, tend to participate in financial market. However, individuals with basic financial literacy level tend to walk away from financial market because the nexus between basic financial literacy and financial market participation is found negative statistically significant. The findings also suggest that peer effect and perceived financial literacy have a positive significant relationship with financial market participation. These findings remain robust after endogenous problem is addressed by employing instrument variable (IV) method, especially Ivprobit regression. Hence, these findings recommend that policy-makers should design and develop financial literacy programs, specifically at sophisticated level, to adapt and overtake the trend in financial innovation development. This should be done, not only on individual, but also national scale to ensure greater financial market participation.
\end{abstract}

Keywords : Financial Literacy, Peer Effect, Financial Market Participation, Vietnam

JEL Classification Code: G53, C92, G11

\section{Introduction}

The fast growth of financial industry has made financial products, instruments and services in financial markets complex and sophisticated in both developed and emerging economies (Ahmed, 2014; Nguyen \& Pham, 2018; Phan, 2018). This trend creates more opportunities for investors to access financial markets via either on-line or off-line. Hence

"The authors are thankful to Ho Chi Minh City Open University for funding this research. We would like to thank the anonymous referees for their helpful comments and suggestions.

${ }^{1}$ First Author and Corresponding Author. Lecturer, Faculty of Finance and Banking, Ho Chi Minh City Open University, Vietnam [Postal Address: 35-37 Ho Hao Hon, District 1, Ho Chi Minh City, 700000, Vietnam] Email: nhu.nta@ou.edu.vn

${ }^{2}$ Associate Professor, Graduate School, Ho Chi Minh City Open University, Vietnam. Email: kieu.nm@ou.edu.vn

(c) Copyright: The Author(s)

This is an Open Access article distributed under the terms of the Creative Commons Attribution Non-Commercial License (http://Creativecommons.org/licenses/by-nc/4.0/) which permits unrestricted noncommercial use, distribution, and reproduction in any medium, provided the original work is properly cited. investors can invest their money to increase their assets and accumulate their wealth by participating in financial markets. However, investors also need to acquire a deep understanding of financial products and financial instruments in order to achieve their financial goals. Specifically, they should have broad knowledge about the key features of a financial transaction such as costs, risk and return. Basically, individual investors are required to build a firm foundation of financial knowledge to make well-informed decisions. Therefore, individual financial decisions have become an important area of research in recent decades.

According to the literature review from personal finance, financial literacy plays a key role in investment decisionmaking and financial well-being (Lusardi \& Mitchell, 2011a). A number of studies have investigated the factors in individual financial market participation in recent years: individual personality (Almenberg \& Dreber, 2015; Campbell, 2006); and social interactions and social capital (Liu, You, \& Zhao, 2013). Although many studies indicate that individuals with better knowledge of financial literacy contribute a lot to their financial well-being (Lusardi \& 
Mitchell, 2011a; Almenberg \& Dreber, 2015), few studies explore the effects of financial literacy on financial market participation. Some recent work has focused on household participation and financial market (Chen et al., 2015; Chetty, SÁndor, \& Szeidl, 2017) and other research has affirmed the role of financial literacy (Almenberg \& Dreber, 2015; van Rooij, Lusardi, \& Mitchell, 2017). However, while most of these studies have examined cases in the Western world as developed economies, there are few cases in Asia or emerging economies. Particularly, to the best of our knowledge, there is no existing study in Vietnam.

In addition, making decisions on financial market participation is a complicated process because of a great deal of uncertainty about future return and earning. Based on studies into the relationship between financial mistakes and perceptive ability as well as experience (Agarwal \& Mazumder, 2013; Bertrand \& Morse, 2011) and the link between thinking cost and financial decisions (Madrian \& Dennis, 2001), investors may seek assistance from their peers in order to reach a wise decision. As reported by the American Institute of CPAs (2013), people normally discuss their retirement schemes with their peers and make decisions based on their financial habits. Therefore, this can be inferred that peer effect could be considered an important factor in financial market participation. Presumably research into peer effects on financial market participation has never been conducted.

In order to discover the impact of financial literacy and peer effect on financial market participation, a set of research questions are posed. The first question asks whether Vietnamese people who currently work in the financial industry or related areas have participated in financial market or not. This is because they are considered to participate in financial market actively and to perform social interaction with peers. The second question challenges whether financial literacy, which includes basic and advanced levels, motivates people to participate in financial market. Finally, in the context of emerging market in developing countries such as Vietnam, whether peer effect factor has influenced people to participate in financial market.

Consequently, the primary objective of this paper is to extend the literature on personal finance by assessing the effect of financial literacy on financial market participation. This paper also contributes to the empirical literature by exploring whether peer-effect factor has any impact on people's motivation for financial market participation in Vietnam emerging market. The Probit and Ivprobit regression models are employed to analyze data.

The paper is structured as follows: Section 2 describes a review of literature and hypothesis development. In section 3, research methodology, method for data collection, measurement of variables and estimation technique are outlined. The final section provides results and discussion, and conclusion.

\section{Literature Review}

\subsection{Financial Literacy and Financial Market Participation}

In recent decades, personal finance has become an attractive research area. A number of studies have been conducted to examine the determinants of individual financial market participation. Many of them have investigated factors which relate to personal socio-economic information and affect individuals' access to financial market such as gender, education level, and income (Almenberg \& Dreber, 2015; Campbell, 2006). Particularly, Almenberg \& Dreber (2015) stated that males have a propensity to participate in stock market in comparison with females. Moreover, Campbell (2006) emphasized the positive correlation between education level and stock market participation. Previous empirical research also demonstrated that household characteristics such as wealth and income sources impact household financial market participation (Betermier et al., 2017; Fagereng et al., 2017).

Further, it is assumed that financial market participation is a sophisticated process that requires a considerable amount of time to search and select information for analysis. In the course of this process, investors' financial knowledge plays an important role and it is considered a key factor in decision on financial market participation. At the first step in raising awareness of finance, these investors are required to understand basic economic and financial concepts such as inflation, interest rate and time value of money. As an illustration of this, one research in Italy indicated that Italian households with low financial awareness tend to have low probability of taking part in financial market (Guiso \& Jappelli, 2005). This finding is similar to other empirical studies which revealed that advanced financial literacy level plays an important role in the process of financial decisionmaking, especially in specialized investment such as stock market participation (van Rooij et al., 2011). To support this argument, Almenberg \& Dreber (2015); and Hsiao \& Tsai (2018) confirmed the significant positive role of financial literacy in stock market and derivative market participation.

Accordingly, as financial innovation could provide diverse financial products and services which have become increasingly complex, financial literacy plays a decisive role in decision-making process for participating in financial market. This factor has been explored extensively in financial articles (Atkinson and Messy, 2011; Calcagno \& Monticone, 2015; Stolper, 2018). Recently, some empirical studies into emerging markets proved that the level of confidence in 
financial literacy is positively correlated with household stock market participation (Xia, Wang, \& Li, 2014). However, financial literacy should be discussed thoroughly to provide more empirical evidence from emerging markets for personal finance literature.

\subsection{Peer Effects in Financial Decision}

Peer effects on social behavior and technology application have been a major center for a large body of empirical literature. Manski (1993) analyzes problems in econometrics in order to recognize peer effects. Indeed, peer effects on social behavior do not necessarily depend on the direct impact of each member. Many theoretical reasons explain how behavior changes to the peer-group average by exchanging peer information. Banerjee (1992); and Ellison and Fudenberg (1993) indicate that peers can copy their counterparts' behavior as this behavior shows useful information relating to their advantages. Also, peer interventions give information on social norms, social reactions, considerations for identity, and strategic complementarities (Benjamin, Choi, and Strickland, 2010). In addition, peer effect is also an important factor in financial decisions. Specifically, peer effects are found to have a relationship with retirement saving outcomes (Duflo \& Saez, 2002), participation in stock market (Hong, Kubik, \& Stein, 2005; Brown et al., 2008), and risk aversion (Ahern, Duchin, \& Shumway, 2013).

According to the theoretical literature, there should be a minimum of two reasons for the important role of peers' impact on behavior. The first reason is that their schemes are unclear so other people may not recognize the benefits if they do not pay full attention. If they still decide to make any financial decisions, they could miss some valuable information. Madrian and Dennis (2001) emphasized that many people do not take these decisions into consideration. However, based on studies conducted by Banerjee (1992); and Elison and Fudenberg (1993), peer information is considered a more significant factor, which makes the greatest contribution to financial decisions. The other reason suggests that social norms can have considerable impact on decisions about savings. People in the same social group could watch each other and copy appropriate behavior as Bernheim (1994) states that people would rather do things common among their peers such as keeping their consumption levels the same as other members. Additionally, regarding social interaction, households who communicate with other people have a propensity to get into financial markets (Hong et al., 2005). Other research also revealed that social interaction and social capital have a positive correlation with participation in stock market (Brown et al., 2008; \& Liu et al., 2013).

\section{Data and Methodology}

\subsection{Data and Variables}

The objective respondents in this research are those who are currently working in finance or related areas such as banking industry, insurance industry, and real estate and securities companies in Ho Chi Minh City. The data was collected in 2019. The survey covers the components comprising basic personal information; basic financial literacy, advanced financial literacy and perceived financial literacy; peer effect; and financial market participation. The questionnaire survey was distributed to 540 respondents in which 387 questionnaires were answered and retained as valid for data analysis.

In this research, financial market participation, a dependent variable, is considered whether an individual has participated in buying, selling or holding financial instruments such as bonds or stocks in financial market. If they do this, the dependent variable is coded a value of 1 ; otherwise 0 value. Similarly, peer effect reflects whether an individual has received information or consultancy from other people such as family members or coworkers. This variable is assumed a value of 1 if they do this; otherwise 0 value. Other main explanatory variables are comprised of basic financial literacy and advanced financial literacy based on Lusardi and Mitchell (2007a,) and van Rooij et al., (2011). Perceived financial literacy is measured by how respondents self-assess their financial knowledge using Likert scale measurement.

\subsection{Measurement of Financial Literacy Level}

Financial literacy indicator in this research is divided into two levels: basic financial literacy and advanced financial literacy based on Lusardi and Mitchell (2007a) and van Rooij et al., (2011). Firstly, to measure basic financial knowledge, respondents answer four multiple choice questions on basic financial concepts such as compound interest, inflation, time value of money, and money illusion. These questions, which are related to financial daily transactions, have also been applied to measure individuals' general financial knowledge of financial planning and financial advice (Lusardi \& Mitchell, 2011a; Stolper, 2018). Secondly, the questions on advanced financial literacy level are constructed based on van Rooij et al., (2011). These questions cover sophisticated knowledge which focuses on the difference between stock and bond investment. Particularly, the objective of this level is to evaluate individual investors' knowledge about perceived performance; volatility and risk diversification; and risk and return concepts. These eight questions on advanced financial literacy level have also been used in empirical research (Xia et al., 2014; Nguyen \& Rozsa, 2019). To measure financial 
literacy of both basic and advanced financial literacy levels, respondents give answers to multiple-choice questions. A correct answer is coded a value of 1 , otherwise 0 value. These answers are captured as dichotomous variables.

Figure 1 details the percentage of individuals giving correct and incorrect or DNK "do not know" responses when they answer questions on basic and advanced financial literacy level. The respondents have a medium level of basic financial literacy in which $57 \%, 64 \%, 58 \%$ and $47 \%$ gave correct answer to questions on compound interest, inflation, time value of money, and money illusion respectively. Regarding advanced financial literacy level, the proportion of correct answers was lower with $33 \%, 34 \%$ and $39 \%$ to long-term period return, performance, and return rating respectively.

\subsection{Control Variables}

This research also applied a set of control variables, which are decisive factors in individual's financial decisionmaking. First, similar to prior research (Almenberg \& Dreber, 2015; Campbell, 2006), individuals' demographic characteristics such as gender, age, education levels, marital status, and the number of children may affect financial market participation. Additionally, variables related to information on individuals' wealth such as income status and home ownership also impact individuals' financial market participation (Chen et al., 2015). Particularly, gender, marital status and home ownership variables are dummy variables coded a value of 1 if individuals are male and otherwise 0 value. Age group, education level, number of children and income level are categorical variables.

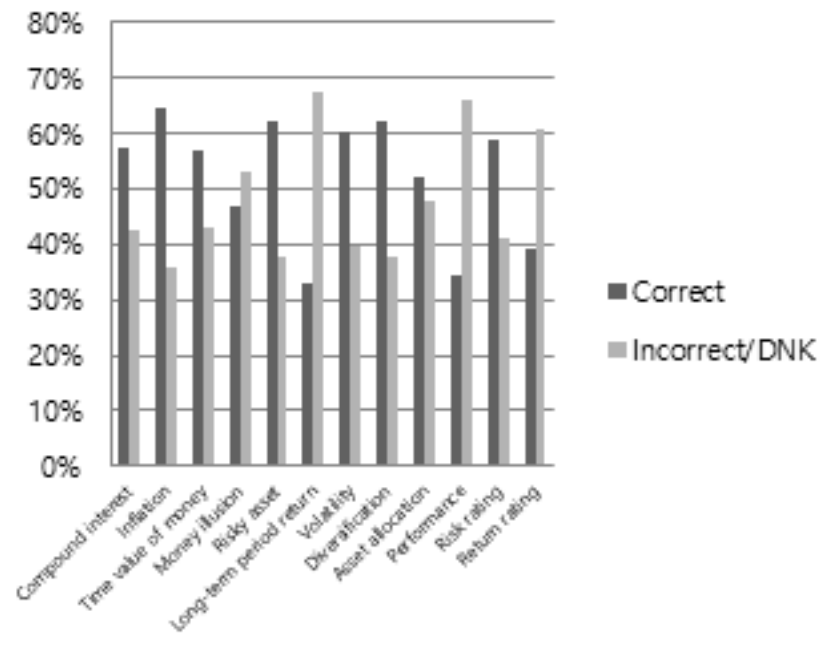

Source: Own calculation based on own research. DNK stands for do not know answer

Figure 1: Answers to basic and advanced financial literacy level questions.
Table 1: Descriptive statistics of the variables

\begin{tabular}{|l|c|c|c|c|}
\hline Variable & Mean & S.D. & Min & Max \\
\hline $\begin{array}{l}\text { Financial market } \\
\text { participation }\end{array}$ & 0.42 & 0.47 & 0 & 1 \\
\hline Basic financial literacy & 2.47 & 1.12 & 0 & 4 \\
\hline Advanced financial literacy & 4.07 & 2.18 & 0 & 8 \\
\hline Perceived financial literacy & 2.63 & 0.99 & 1 & 5 \\
\hline Peer effect & 0.39 & 0.488 & 0 & 1 \\
\hline Gender & 0.43 & 0.50 & 0 & 1 \\
\hline Age & 2.21 & 0.79 & 1 & 4 \\
\hline Education & 1.65 & 0.60 & 1 & 3 \\
\hline Marital status & 0.63 & 0.48 & 0 & 1 \\
\hline Dependent person & 0.53 & 0.50 & 0 & 3 \\
\hline Income & 1.72 & 0.81 & 1 & 3 \\
\hline Home & 0.48 & 0.50 & 0 & 1 \\
\hline Number of observations & 387 & & & \\
\hline
\end{tabular}

Table 1 shows the summary statistic of variables applied in this research. The percentage of individuals participating in financial market is around $42 \%$. Just approximately $39 \%$ of respondents have received advice or share information with their family members or coworkers. Among the main independent variables, perceived financial literacy and advanced financial literacy level have an average level with mean value of 2.63 and 4.07 respectively while basic financial literacy is slightly higher than average score with mean value of 2.47 .

\subsection{Research Model}

First, the Probit model is applied to examine the role of financial literacy in individuals' financial market participation. Assume that for individual i, the decision to participate in financial market can code two values, 1 for those who have participated and 0 for otherwise.

$$
\begin{aligned}
Y_{i}= & \alpha+\beta_{1} B F L_{i}+\beta_{2} A F L_{i}+\beta_{3} P F L_{i} \\
& +\beta_{3} P E_{i}+\theta X_{i}+\varepsilon_{i}
\end{aligned}
$$

Where, $\beta_{1}, \beta_{2}, \beta_{3}$ and $\theta_{\mathrm{i}}$ are the parameters to be estimated; $\mathrm{X}_{\mathrm{i}}$ is other control variables and $\varepsilon_{\mathrm{i}}$ is a random error. $\mathrm{BFL}$, AFL, PFL and PE stand for basic financial literacy; advanced financial literacy; perceived financial literacy and peer effect respectively.

However, in equation (1), the error term may include unobserved variables which impact individuals' financial market participation and their financial literacy level. Hence 
the Probit estimation may lead to biased results for the as endogeneity problem occurs. To deal with this issue, IV (instrumental-variables) method was applied to address the endogenous problem. Based on previous studies (Jappelli \& Padula, 2013; van Rooij al., 2011), the variables are suggested as instrument variables of financial literacy comprising respondents' financial training course or financial education and parent's education level of respondents. There could be a correlation between these variables and financial literacy level but they may not be related to financial market participation. Accordingly, this research also applied these variables in IV method. In this situation this research applied the Ivprobit model.

\section{Results and Discussion}

Table 2 reports the estimation results of the factors that impact individuals' participation in financial market. The first and second columns display the results from the Probit estimation method. Column 1 was estimated with financial literacy variables and control variables but without peer effect. Column 2 includes financial literacy, peer effect, and control variables. The third column reports and confirms the results when the endogenous problem is controlled by estimating Ivprobit regression with instrument variables.

The results of the Probit estimation method in column 1 show that the nexus between financial market participation and financial literacy including both basic and advanced levels is positively correlated and statistically significant. However, perceived financial knowledge has no statistically significant effect. In other words, perceived financial knowledge of respondents is not related to whether they participate in financial market or not but those who have greater financial knowledge are more likely to participate in this market. This result is in accordance with previous research (Chu et al., 2017). In addition, the result reports that education is found to have a positive influence upon the possibility of participating in financial market. This finding is also supported by Mankiw and Zeldes (1991). These researchers explained that individuals with better education reduce the cost of collecting and analyzing information on financial market and have a propensity to take part in financial market. Remarkably, this finding also indicates that people with diploma or undergraduate have a higher probability of participating in financial market compared to those with lower level of education.

In column 2, peer-effect factor is employed in the Probit regression to investigate whether peer effect has impact on individuals' financial market participation. The results show that the probability of participating in financial market rises as individuals have received peer effects, besides both basic and advanced financial literacy. Furthermore, when peereffect factor was added to the estimation, gender factor also
Table 2: Multivariate analysis of market participation

\begin{tabular}{|c|c|c|c|}
\hline & $\begin{array}{c}\text { Probit } \\
\text { (1) }\end{array}$ & $\begin{array}{l}\text { Probit } \\
\text { (2) }\end{array}$ & $\begin{array}{l}\text { Ivprobit } \\
\text { (3) }\end{array}$ \\
\hline \multirow[t]{2}{*}{ Basic financial literacy } & $0.54^{* \star *}$ & $0.51^{* \star \star}$ & $-0.79^{\star * *}$ \\
\hline & $(0.11)$ & $(0.11)$ & $(0.28)$ \\
\hline \multirow[t]{2}{*}{ Advanced financial literacy } & $0.36^{* * *}$ & $0.36^{* * *}$ & $0.59^{* * *}$ \\
\hline & $(0.06)$ & $(0.07)$ & $(0.05)$ \\
\hline \multirow[t]{2}{*}{ Perceived financial literacy } & 0.13 & 0.12 & $0.18^{* *}$ \\
\hline & $(0.10)$ & $(0.10)$ & $(0.07)$ \\
\hline \multirow[t]{2}{*}{ Peer effect } & & $0.72^{* * \star}$ & $0.50^{* *}$ \\
\hline & & $(0.18)$ & $(0.21)$ \\
\hline \multirow[t]{2}{*}{ Male } & -0.25 & $-0.32^{*}$ & -0.13 \\
\hline & $(0.18)$ & $(0.19)$ & $(0.15)$ \\
\hline \multicolumn{4}{|l|}{ Age } \\
\hline \multirow[t]{2}{*}{ - $26-35$ age } & 0.06 & 0.10 & 0.02 \\
\hline & $(0.30)$ & $(0.30)$ & $(0.20)$ \\
\hline \multirow[t]{2}{*}{ - 36-50 age } & 0.19 & 0.21 & 0.03 \\
\hline & $(0.36)$ & $(0.37)$ & $(0.26)$ \\
\hline \multirow[t]{2}{*}{$-51-60$ age } & 0.32 & 0.32 & 0.33 \\
\hline & $(0.52)$ & $(0.52)$ & $(0.35)$ \\
\hline \multicolumn{4}{|l|}{ Education } \\
\hline \multirow[t]{2}{*}{ Undergraduate } & $0.53^{* *}$ & $0.50^{* *}$ & 0.14 \\
\hline & $(0.22)$ & $(0.23)$ & $(0.24)$ \\
\hline \multirow[t]{2}{*}{ Postgraduate } & 0.21 & 0.30 & -0.32 \\
\hline & $(0.39)$ & $(0.39)$ & $(0.36)$ \\
\hline \multirow[t]{2}{*}{ Married } & 0.45 & 0.27 & $0.41^{*}$ \\
\hline & $(0.34)$ & $(0.34)$ & $(0.24)$ \\
\hline \multirow[t]{2}{*}{ Dependent person } & 0.40 & -0.41 & -0.34 \\
\hline & $(0.32)$ & $(0.32)$ & $(0.24)$ \\
\hline \multicolumn{4}{|l|}{ Income } \\
\hline \multirow[t]{2}{*}{ - 9-15 million VND } & -0.03 & -0.08 & 0.09 \\
\hline & $(0.23)$ & $(0.23)$ & $(0.16)$ \\
\hline \multirow[t]{2}{*}{ - >15 million VND } & 0.09 & 0.01 & $0.47^{* *}$ \\
\hline & $(0.26)$ & $(0.25)$ & $(019)$ \\
\hline Number of observations & 387 & 387 & 387 \\
\hline Pseudo R2 & 0.49 & 0.53 & \\
\hline Wald & & & 21.93 \\
\hline
\end{tabular}

The coefficients with * $p<0.1,{ }^{* *} p<0.05$, ${ }^{* *} p<0.01$. Standard errors in parentheses

displays statistical significance. Particularly, men have a negative relationship with financial market participation in comparison with women. This can be explained that when individuals received financial advice or consultancy, women are affected by peer effects more greatly than men 
and they have a propensity to participate in financial market. Previous research also argued that social interaction in people's working or living environment could influence their financial decisions (Hong, et al., 2005; Guiso, Sapienza \& Zingales 2008).

Lastly, the results in column 3 controlled the endogenous problem by using instrumental variables (IV) in the Ivprobit model. It can be seen that financial literacy, perceived financial literacy and peer-effect indicator are statistically significant. Particularly, the results show that financial market participation is found to have a negative relationship and statistical significance with basic financial literacy level. However, this factor is positively correlated and statistically significant with advanced financial literacy level, perceived financial literacy knowledge and peer effect. This can be interpreted that individuals' participation in financial market could probably be impacted by their sophisticated financial knowledge level. In other words, individuals are more likely to participate in financial market when they have achieved a higher level of advanced financial literacy. This finding is in line with prior studies by Chu et al. (2017); Nguyen and Rozsa (2019); and van Rooij et al. (2011). These researchers have also found evidence that people with sophisticated financial knowledge level tend to participate in financial market, specifically in stock market. Accordingly, it can be inferred that basic financial knowledge level is more likely to have significant effects on uncomplicated choices. This means in the context of emerging market such as Vietnam individuals with basic financial literacy have a tendency to walk away from financial market participation. However, in order to deal with more complex choice to participate in financial market, self-assessed financial knowledge and advanced financial knowledge level are more important factors. This means those who are confident about their financial knowledge presented by high level of perceived financial knowledge are more likely to participate in financial market. This is similar to those who have advanced financial literacy level.

Moreover, the impact of peer-effect indicator has similar results before endogenous problem is controlled by employing the Probit regression in column 2 and after this problem is addressed by the Ivprobit method in column 3 . Particularly, peer-effect indicator has a positive statistically significant relationship with participation in financial market. This finding provides more empirical evidence to the literature on this research area and it is also in line with prior studies (Hong, et al., 2005; Liu et al., 2013).

Regarding control variables, the signs of coefficients of these variables follow theoretical analyses. The result indicates that marital status and high income level have a positive effect on the probability of individuals' financial market participation. This result suggests that individuals with high income tend to participate in financial market, particularly when comparing to people with income of under 15 million VND. This result is consistent with empirical findings from previous studies (Guiso, Haliassos \& Jappelli 2003; Campbell 2006). However, education factor is found not to have an impact on individuals' financial market participation after endogenous problem is addressed, but this finding inverts the result when the endogenous problem has not been resolved yet.

\section{Conclusions}

In this paper, we contribute to the literature on personal finance by investigating the effects of both financial literacy levels and peer effect on financial market participation. Basic financial literacy level is considered general knowledge related to daily transactions of individuals, while advanced financial literacy level focuses more on sophisticated knowledge related to risky asset matters and investment performance. The results show that advanced financial literacy level and perceived financial literacy have positive and statistically significant impact on individual financial market participation, whereas basic financial literacy has a significant negative influence on individual financial market participation. Hence it can be inferred that those who are confident in their financial literacy and those with higher level of advanced financial knowledge may have a propensity to participate in financial market. Furthermore, this study also examines the role of peer effect in individuals' financial market participation. The finding suggests that, besides financial literacy, peer effect also plays a significant role in financial market participation. Indeed, not only advanced financial knowledge level, but also peer-effect indicator affects individuals' financial market participation.

Regarding recommendations we suggest that policymakers should create and develop financial literacy programs so that people can acquire better understanding of financial knowledge and become more confident to take part in financial market. Future work should examine options of accumulating individual investor's assets and assess the effects of household financial literacy on investment performance.

\section{References}

Agarwal, S., \& Mazumder, B. (2013). Cognitive abilities and household financial decision making. American Economic Journal: Applied Economics. 5(1), 193-207. https://doi.org/10.1257/app.5.1.193.

Ahern, K. R., Duchin, R., \& Shumway, T., (2014). Peer Effects in Risk Aversion and Trust. The Review of Financial Studies, 27(11), 3213-3240. https://doi.org/10.1093/rfs/hhu042. 
Ahmed, I., (2014). Emerging Trends of Financial Markets Integration: Evidence from Pakistan. Journal of Asian Finance, Economics and Business, 1(1), 15-21. https://doi.org/10.13106/ jafeb.2014.vol1.no1.15.

Almenberg, J., \& Dreber, A. (2015). Gender, stock market participation and financial literacy. Economics Letters, 137, 140-142. https://doi.org/10.1016/j.econlet.2015.10.009.

American Institute of CPAs (2013). New survey finds millennials rely on friends' financial habits to determine their own. Retrieved December 17, 2019, from http://www.aicpa.org/Press/PressReleases/2013/.

Atkinson, A., \& Messy, F. A. (2011). Assessing financial literacy in 12 countries: an OECD/INFE international pilot exercise. Journal of Pension Economics and Finance, 10(4), 657-665. https://doi.org/10.1017/S1474747211000539.

Banerjee, A., (1992). A simple model of herd behavior. The Quarterly Journal of Economics, 107(3), 797-817.

Benjamin, D. J., Choi J. J., \& Strickland, A. J., (2010). Social Identity and Preferences. American Economic Review, 100 (4), 1913-1928. DOI: 10.1257/aer.100.4.1913

Bernheim, B D., (1994). A Theory of Conformity. Journal of Political Economy, 102(5), 841-877. DOI:10.1086/261957

Bertrand, M., \& Morse, A., (2011). Information Disclosure, Cognitive Biases, and Payday Borrowing. Journal of Finance, 66(6), 1865-1893. https://doi.org/10.1111/j.15406261.2011.01698.x

Betermier, S., Calvet, L. E., \& Sodini, P. (2017). Who are the value and growth investors? Journal of Finance, 72(1), 5-46. https:// doi.org/10.1111/jofi.12473

Brown, J. R., Ivkovic Z., Smith, P.A., \& Weisbenner, S., (2008). Neighbors Matter: Causal Community Effects and Stock Market Participation. The Journal of Finance, 63(3), 15091531. https://doi.org/10.1111/j.1540-6261.2008.01364.x

Calcagno, R., Moticone, C. (2015). Financial literacy and the demand for financial advice. Journal of Banking \& Finance, 50, 363-380. https://doi.org/10.1016/j.jbankfin.2014.03.013

Campbell, J. Y. (2006). Household finance. Journal of Finance, 61(4), 1553-1604.

Chen, Y., Shi, Y., \& Kown, O. S. (2015). Housing wealth, financial market participation and household portfolio choice: Evidence from china's urban district. Journal of Financial Research, 4, $1-18$.

Chetty, R., SAndor, L., \& Szeidl, A. (2017). The effect of housing on portfolio choice. Journal of Finance, 72(3), 1171-1212. https://doi.org/10.1111/jofi.12500.

Chu, Z., Wang, Z., Xiao, J. J., \& Zhang, W., (2017). Financial Literacy, Portfolio Choice and Financial Well-Being. Social Indicators Research, 132, 799-820. https://doi.org/10.1007/ s11205-016-1309-2.

Duflo, E., \& Saez E., (2002). Participation and investment decisions in a retirement plan: The influence of colleagues' choices, Journal of Public Economics, 85(2002), 121-148.
Ellison, G., \& Fudenberg, D., (1993). Rules of thumb for social learning, Journal of Political Economy, 101(4), 93-126. https:// doi.org/10.1086/261890

Employee Benefit Research Institute, (2008). The 2008 Retirement Confidence Survey. Issue brief. Retrieved January 30, 2019, from https://www.ebri.org/pdf/briefspdf/EBRI_IB_04-2008.pdf.

Fagereng, A., Gottlieb, C., \& Guiso, L. (2017). Asset market participation and portfolio choice over the life-cycle. Journal of Finance, 72(2), 705-750. https://doi.org/10.1111/jofi.12484

Guiso, L., Haliassos, M., \& Jappelli, T. (2003). Household stockholding in Europe: Where do we stand and where do we go? Economic Policy, 18(36), 123-170. https://doi. org/10.1111/1468-0327.00104

Guiso, L., \& Jappelli, T. (2005). Awareness and stock market participation. Review of Finance, 9(4), 537-567. https://doi. org/10.1007/s10679-005-5000-8

Guiso, L., Sapienza, P., \& Zingales, L., (2008). Trusting the Stock Market. The Journal of Finance, 63(6), 2557-2600. https://doi. org/10.1111/j.1540-6261.2008.01408.x.

Hong, H., Kubik, J.D., \& Stein, J. C., (2005). The neighbor's portfolio: word-of-mouth effects in the holdings and trades of money managers. The Journal of Finance, 60(6), 2801-2824. https://doi.org/10.1111/j.1540-6261.2005.00817.x.

Hsiao, Y. J., \& Tsai, W. C. (2018). Financial literacy and participation in the derivatives markets. Journal of Banking \& Finance, 88 , 15-29. https://doi.org/10.1016/j.jbankfin.2017.11.006.

Jappelli, T., \& Padula, M. (2013). Investment in financial literacy and saving decisions. Journal of Banking \& Finance, 37(8), 2779-2792. https://doi.org/10.1016/j.jbankfin.2013.03.019.

Liu, Y., Meng, J., You, W. \& Zhao, L. (2013). Word-of-mouth Communication, Observational learning, and Stock Market Participation. Social Science Electronic Publishing. Retrieved from SSRN: https://ssrn.com/abstract=2251570.

Lusardi, A., \& Mitchell, O. S. (2007b). Financial literacy and retirement preparedness: Evidence and implications for financial education programs. Business Economics, 42(1), 33-34.

Lusardi, A., \& Mitchell, O. S. (2011a). Financial literacy and retirement planning in the United States. Journal of Pension Economics \& Finance, 10(4), 509-525. https://doi.org/10.1017/ S147474721100045X.

Lusardi, A. \& Mitchell, O. S., (2017). How Ordinary Consumers Make Complex Economic Decisions: Financial Literacy and Retirement Readiness. Quarterly Journal of Finance, 7(03), 1-31. DOI: 10.1142/S2010139217500082.

Madrian, B., \& Dennis, S., (2001). The power of suggestion: inertia in $401(\mathrm{k})$ participation and savings behavior. The Quarterly Journal of Economics. 116(4), 1149-1187. https:// doi.org/10.1162/003355301753265543.

Mankiw, N. G., \& Zeldes, S. P., (1991). The Consumption of Stockholders and non-stockholders. Journal of Financial Economics, 29, 97-112. https://doi.org/10.1016/0304405X(91)90015-C 
Manski, C. F., (1993). Identification of Endogenous Social Effects: The Reflection Problem. Review of Economic Studies, 60(3), 531-542. DOI: $10.2307 / 2298123$

Nguyen, D. D., \& Pham, M. C., (2018). Search-based Sentiment and Stock Market Reactions: An Empirical Evidence in Vietnam. Journal of Asian Finance, Economics and Business, 5(4), 45-56. http://doi.org/10.13106/jafeb.2018.vol5.no4.45

Nguyen, T. A. N., Rozsa, Z. (2019). Financial Literacy and Financial Advice Seeking for Retirement Investment Choice. Journal of Competitiveness, 11(1), 70-83. https://doi.org/10.7441/ joc.2019.01.05

Phan, T. L. (2018). The Relationship between Perceived Access to Finance and Social Entrepreneurship Intentions among
University Students in Vietnam. Journal of Asian Finance, Economics and Business, 5(1), 63-72. http://dx.doi. org/10.13106/jafeb.2018.vol5.no1.63

Stolper, O. (2018). It takes two to Tango: Households' response to financial advice and the role of financial literacy. Journal of Banking \& Finance, 92, 295-310. https://doi.org/10.1016/j. jbankfin.2017.04.014

van Rooij, M., Lusardi, A., \& Alessie, R. (2011). Financial literacy and stock market participation. Journal of Financial Economics, 101(2), 449-472. https://doi.org/10.1016/j.jfineco.2011.03.006

Xia, T., Wang, Z., \& Li, K. (2014). Financial literacy overconfidence and Stock market participation. Social Indicators Research, 119(3), 1233-1245. DOI:10.1007/s11205-013-0555-9 